\title{
In Vino Veritas: Old Wine Markets in New Global Economic Battles
}

\author{
In vino veritas: antiguos mercados vinícolas en modernas \\ batallas económicas
}

WILLIAM M. HAWLEY

INDEPENDENT SCHOLAR

Artículo recibido el / Article received: 18-08-2013

Artículo aceptado el / Article accepted: 21-02-2014

ABSTRACT: Wine markets have supported regional cultures and international alliances for centuries. Renaissance diplomatic and dramatic language refers to French markets, not economies, extending globally from Bordeaux to the Far East. Yet Shakespeare invents our representation of the global economy's illgotten gains and predatory speculation in wine (and other) markets. Prince Hal leverages the very wine market that he derides obsessively into a narrative of sin and redemption. Hal consummates his narrative by rejecting Falstaff, whom he identifies as an earthly Bacchus. But Burgundy's pragmatic representation of the excellence of viniculture in Henry $V$ fits the paradigm of sustainable marketplaces in part because the symbolism of fine wine is universally esteemed. Today's economic crisis proves that the quasi-Hegelian idea of an ethical economy cannot be attained through financial interdependence alone. Moreover, it validates the Renaissance narrative that responsible wine markets improve with age.

Keywords: wine, markets, Shakespeare, Renaissance, representation, pragmatism.

RESUMEN: Los mercados vinícolas han apoyado las culturas regionales y las alianzas internacionales durante siglos. El lenguaje diplomático y teatral del Renacimiento hace alusión a los mercados franceses y no a las economías, expandiéndose globalmente desde Burdeos hasta el Lejano Oriente. Es Shakespeare quien inaugura las representaciones de la especulación depredadora y las ganancias ilícitas en la economía global a través de los mercados vinícolas (y otros). El príncipe Hal provoca el endeudamiento del mercado vinícola que él mismo ridiculiza obsesivamente por medio de narrativas ancladas en el pecado y la redención, así como con su relato rechazando a Falstaff, al que identifica con un mundano Baco. Sin embargo, la representación pragmática que Borgoña hace 
sobre la excelencia de la viticultura en Enrique $V$ se corresponde con el paradigma de los mercados sostenibles, en parte debido al simbolismo de que un buen vino es valorado universalmente. La crisis económica actual pone de manifiesto la idea cuasi hegeliana de que no se puede conseguir una economía ética únicamente por medio de la interdependencia financiera, e incluso valida la narrativa renacentista de que los mercados vinícolas responsables mejoran con la edad.

Palabras clave: vino, mercados, Shakespeare, Renacimiento, representación, pragmatismo.

Modern representations of the global economic crisis owe a debt to Renaissance diplomatic and dramatic language concerning wine marketplaces. In the lexicon of early modern Britain, markets extend globally, while economics refers solely to household budgets. A «free market in London» meant that merchants could sell imported wine without paying extraordinary surcharges (Green, 1872: 661). Approved merchants sold wine in «overt markets», implying that unofficial global exchanges flourished in the shadows (Green, 1872: 656). Renaissance markets endured crises like those afflicting today's global economy due to leverage and arbitrage. Parliamentarian Ralphe Maddison (1641: 1) critiqued trade imbalances that seemed «mysticall» to his peers. But wine markets stabilized international relations between England and France long after Britain lost possession of Aquitaine in 1453. Markets from Bordeaux to Burgundy sustained French viniculture and satisfied English palettes due in part to the symbolic discourse of wine connoisseurship spoken by those vying for power in Renaissance Europe. Indeed, Shakespeare invents our representation of global economic failures by showing the expropriation of healthy wine narratives by power brokers suffering from identity crises.

Renaissance wine markets had a global reach without being globalized. Localities and regional experts maintained the quality and control of vintages. David Hancock (2009: 405) is among the excellent scholars of wine history who see a teleological development in the integration of old marketplaces into the global economic regime: «The globalization of [wine] trade in the nineteenth century also built upon networked approaches and self-organized systems inherited from the eighteenth century». Yet narratives about the inexorable triumph of the global economy ignore crucial language on marketplace ethics in early modern British diplomacy and drama. Renaissance diplomats encouraged British policymakers to trade with peaceful wine markets rather 
than fight over hostile commercial territory. Shakespeare's Henry $V$ and two parts of Henry $I V$ stage wine markets as arenas of strife between modern and classical narratives shaping Hal's identity as king. Hal's stunning victory in the civil war is eclipsed by the symbolism of his rejection of Falstaff, whom he denounces as a degenerated Bacchus. Ironically, both Hal and Falstaff discount the true value of wine marketplaces. Falstaff's overindulgence in spirits is déclassé, while Hal's display of newly-minted piety in shunning taverns seems hypocritical. But Falstaff's defense of wine based on classical medical theory helps to create the narrative of modernity, as Harold Bloom (1987: 2) suggests: «Representation itself changed permanently because of Hamlet and Falstaff». Wine persists in our representation of the global economy because its traditional symbolic value is equaled only by jewels and gold. Crucially, early modern Britain preferred excellent French and Rhenish wines to cheaper vintages available globally.

\section{Economic versus Diplomatic Narratives about Wine Markets}

Britain's financial decline under Charles I caused policymakers to seek reforms in international markets. Maddison presented his findings to Parliament in 1640 by "setting forth "the depth of the mystery of trade"» (Bruce, 1858: 204). He blamed foreign usury and debasement of coins for England's economic woes. He proposed resetting exchange rates weekly in order to defend Britain from international fraud and currency speculation. Maddison (1641: 1) accused «Bankers or lenders of monies beyond Seas» of manipulating foreign markets at Britain's expense. His monetary solution to perceived trade inequalities required closing French markets to British trade, although England's demand for French wine rose steadily throughout the Renaissance. Elizabeth I had asked ambassador Francis Walsingham to ensure «the safety of the English Merchants now repairing to the Vintage [...] to the town of Burdeaux» after the St. Bartholomew's Day massacre of 1572, when French religious strife endangered visiting Protestant traders (Digges, 1655: 249). James I's trade policy was even more expansive than Elizabeth's. James decreed that new French vintages could be discharged on English shores annually after December $1^{\text {st }}$, a limitation designed to ensure the quality of the imported product. English Renaissance diplomatic narratives overcame Maddison's argument for protectionism, variations of which are extant today.

To his credit, Maddison believed that sound policies could correct abuses in international commerce: «The rise in exchange in King James's time was 
the result of an act of state» (Bruce, 1858: 204). Yet his pre-mercantilist theory slighted James's peace treaties with European competitors that spurred imports of quality commodities like French wine. In effect, James fulfilled the hope expressed by Francis Walsingham in 1571 that Britain might cease fighting over hostile northern European markets in order to cultivate peaceful commercial ties with wine producers in Bordeaux and Burgundy: «And though France cannot yield profit that Flanders doth, yet may it yield some profit with less hazard, and more safety» (Digges, 1655: 121). British commerce with benign European and Far Eastern markets produced gains that outstripped by far any losses resulting from debased French coins or unfair currency valuations.

Maddison's worst fears about Charles's monetary policy were realized two years after the publication of his treatise with the start of the English Civil War. His long-held view that financial «Leakes in this Ship or house» would result in popular uprisings proved prescient (1641: 1). But Walsingham's diplomatic approach to global commerce was every bit as realistic as Maddison's. Both men knew that entrenched constituencies in government could never allow England to forsake entirely her interests in war-torn northern Europe; however, their theories about the marketplace were based upon different foundations altogether. Maddison proposed blocking international trade in order to safeguard England's reserves of precious metals. Walsingham argued pragmatically that increasing the quantity and quality of trade between peaceful foreign markets would yield a solid return on investment. Walsingham's diplomatic rationale prevailed because England depended upon imports for her survival. Britain's consumption of wine was discretionary, but her populace would have flouted Maddison's laws halting the importation of French vintages.

Maddison (1641: v) critiques astutely Britain's «home-bred monopolian [monopolistic] practices» that stifled marketplace growth. Monopolies contracted the money supply, causing domestic recessions while devaluing British currency abroad. But Maddison's analysis is torn between explaining the logic of devaluation and accusing French bankers of fraud. Like their European counterparts, French banks held foreign currency reserves to allow some visiting traders to buy wine on contract, eliminating the need for merchants to transport their own bullion overseas. A weak English currency allowed French banks to devalue British coins by $10 \%$ even though France debased her coins with alloys like copper, a practice resulting from turmoil on the Continent dating from the 1590s. Maddison (1641: 27) asked his peers to note carefully foreign governments' "new expressions» in denominating their currency. He saw protecting British currency as the key to «maintaine the price of our kingdoms commodities, rents, and artizens» (1641: 24). But he would 
have plunged England into a depression if he had succeeded in restricting British imports to the barest essentials in a vain attempt to hoard domestic gold and silver reserves.

Diplomats like Walsingham proposed resolving monetary inequalities by expanding political and cultural relations with high-quality French wine marketplaces. They viewed as equitable the exchange of British wool, textiles, lead, and tin for French wine. They knew that the military expenditures required to pacify hostile European markets could never be recouped. As well, Elizabeth's closest advisor, Lord Burleigh, saw an advantage in developing trade relations with historical allies instead of crossing swords with powerful foes: «The amitie that we made most account of, was that which this crown had with the house of Burgundy, and not with Spain» (Digges, 1655: 370). No British official proposed eliminating all trade barriers, but the crown's most highly placed advisors held that robust marketplace activity raised domestic living standards partly through the importation of superior wines whose quality was assured by local connoisseurs and cultural institutions.

Wine markets contributed to the demise of Maddison's vision of an insulated British marketplace. The old adage that British wine could be consumed only through clenched teeth and closed eyes suggested that French wine would enter England's markets through normal or illicit channels. The British crown was loathe to relinquish its prisage of two tuns out of every twenty tuns of imported wine as well as its butlerage of two shillings per tun of foreign vintages. As well, James granted wine monopolies for his personal gain. He approved the Earl of Southampton's monopoly on «sweet wines coming into the realm, at the rent of 6,000£» (Green, 1872: 427-428). The crown was said to «farm» the «impost» of the monopolists' trade (Green, 1872: 427). Specialized wines from small European markets like Crete were strong candidates for leasing by monopolists, whereas French wines were difficult to monopolize because of their sheer volume. Furthermore, James waived customs fees on the prodigious quantities of wine imported by foreign ambassadors. The allure of French wine trumped all arguments favoring harsh restrictions on international commerce.

Despite bad harvests and awkward transportation systems, French wine markets remained islands of relative prosperity. The Church's possession of vast tracts of low-tax arable land helped to sustain French viniculture. Farmers producing grain at a subsistence level found that planting their fields with vines increased their incomes. Thus, international wine traders and producers were extremely well positioned in France's economy. The ports of La Rochelle, Nantes, and Bordeaux profited by shipping wine abroad. Marcel Lachiver (1988: 123) estimates that by 1510 wine in excess of « 80000 tonneaux dans 
les années exceptionelles» reached London, which regained its status as a «bon client». France's Henri IV depended upon wine export duties to fund his state, a brute fact that was ignored occasionally by Parisian politicians. But the quality of French wine markets drew English traders despite export tariffs and religious differences. Strong commercial ties encouraged France and England to form alliances in defusing threats from Spain and Northern Europe. On the personal level of international relations, Henri admired Elizabeth's character, which showed in «un brave langage et un plaisant style» of her correspondence (Xivrey, 1843: 227).

Wine had a corrosive effect on border restrictions between France and England. Perishable wines needed to proceed expeditiously through English customs given that foul weather and contrary winds constantly delayed Channel departures. Adverse weather conditions could ruin the product in transit even though connoisseurs stationed at ports like Bordeaux added a layer of quality control to vintages exported internationally. Most importantly, wine crossed borders because it was celebrated worldwide on the symbolic level. Anthony Reid (1989: 39) reports that Dutch explorer Frederick de Houtman attended a water feast presented by Sultan ala'ud-din Ri'ayat Syah of Aceh (Sumatra) that included "very strong brandywine», probably Spanish eau ardente shipped to the Far East aboard Portuguese vessels. The trade in spirits exerted an especially strong influence on British rulers, whose tenure in office depended in part on their respect for wine market narratives.

\section{Healthy Narratives of Renaissance Wine Markets}

Classical medical philosophy casts an aura of truth and respectability upon Renaissance narratives extolling the benefits of wine consumption. Consequently, impediments to the free transportation of wine were viewed in a negative light. Exorbitant expenses became a source of intense irritation for wine merchants forced to tarry at ports of call. Diplomats endured price gouging while languishing at border checkpoints, where «frontier news are never of any great value», making foreign postings an added hardship (Digges, 1655: 21). Walsingham's foreign policy expertise was wasted during stops at «frontiers», which were «commonly better furnished with fables then matters of truth» (Digges, 1655: 21). Thus, classical representations of the medicinal value of wine taken in moderation placed viticulture in a category affirming the received wisdom of the ancients. 
The gustatory pleasures and medicinal benefits of wine had long made it a staple in Britain. William Turner's 1562 publication, A New Boke of the Natures and Properties of all Wines that are commonly used here in England, draws heavily upon the classical medical philosophy of Galen and Hippocrates. Turner feared that Elizabethan England lacked the intellectual drive to grasp time-honored narratives about the connoisseurship and medical applications of wine. Galen famously used wine for a variety of therapeutic procedures. He selected wine to disinfect wounds because it was stronger than water without being overly astringent. He assigned each variety a specific remedial function for internal medical ailments. Galen's knowledge of Mediterranean and northern European wines made him a connoisseur, but his philosophical training and medical prowess lent his commentary a special authority in the Renaissance. Turner wished to elevate Britain's wine connoisseurship based on ancient theories of wellness through viniculture. The English were more familiar with Rhenish than French vintages until the accession of James I, who opened many wine-producing markets to English traders. Britain's close ties to northern Europe account for the popularity of Rhenish wines, but French vintages regained favor as a result of stabilized markets in La Rochelle and Bordeaux following Henri IV's settlement of domestic religious divisions.

Turner was justified in believing that Britain had not benefitted completely from knowledge about wine contained in classical treatises. English physicians lacked many wines prescribed by Galen to treat wounds at various stages in the healing process, particularly during suturing procedures. Galen used dry white wines from the Middle East and Europe to clean fresh wounds because of their styptic and cooling properties. But he found that «wines that are both sweet and tawny orange like the Falernian are unsuitable» for fresh wounds because they heat the inflamed tissue, although they could be used to reduce scarring as the injury healed (Johnson, 2011: 149). Even if Galen's humour theory proved to be unfounded, his surgical techniques were superior to those of most Renaissance practitioners as a result of his five years of experience healing traumatic injuries at Alexandria's Coliseum. As well, Galen ranked wines according to quality ranging from vinegar to vintages of «good quality», such as «Sabine, Adrian, and Alban, and like the Arsyine and the Titacazene» (Johnson, 2011: 279). Few Renaissance winemakers could afford to meet Galen's ten-year standard for aging spirits properly, but his readers learned of vintages from distant regions as a result of his encyclopaedic knowledge of wine.

Falstaff's self-serving pronouncements on classical Greek and Roman medical theory relating to wine connoisseurship exceeded the common 
understanding in Britain. Even connoisseurs in early modern Bordeaux scarcely attained Galen's level of sophistication regarding table wines. Yet the medical theories of Hippocrates, Galen, and Dioscurides counted heavily for traveling British diplomats whose advanced age, remote postings, and arduous journeys required them to rely upon established medical advice. Illness was the primary reason diplomats sought relief from their assignments abroad. Thus, English connoisseurship cannot be discounted entirely. In 1366, wine deemed by Edward III's butler, William de Strete, to be «unsaleable in London on account of its thinness» was shipped promptly to Scotland for resale (Bain, 1888: 27). De Strete consigned «20 casks of Gascon wine of poor colour» to the same fate (Bain, 1888: 47). However, Scotland became a viable destination for fine wines. James VI (later James I of England) purchased wines from France, Italy, and the Middle East via London, including «two buttes of Romaneye, four buttes of Malueseye, [and] a barrel of Tyre» (Bain, 1888: 197-198). Henry VIII and Cardinal Wolsey may have enjoyed the finest wine during sumptuous entertainments at court, but James I followed suit with equal aplomb in early $17^{\text {th }}$ century Scotland and England.

A robust wine infrastructure would have ameliorated but not resolved all inequalities in the British marketplace. England could never hope to equal France as a wine producer, but her rulers never formulated policies to develop wine and wine-related products into second-tier industries benefitting British coopers, metalworkers, bottle makers, horticulturalists, enologists, and consumers. Britain's Channel Islands were capable of producing fair wines and excellent apple brandy. Venice ruled the market in fine wine stemware until Britain stumbled upon a method to integrate lead and glass, enabling domestic artisans to produce valuable drinking vessels by the end of the $17^{\text {th }}$ century. The vitality of the English wine market was sapped by failed policies, not low wages and cheap products abroad. But England patronized fine French wine producers based upon narratives of health and connoisseurship dating from classical times.

\section{Pragmatic Representations of Renaissance Wine Markets}

Renaissance wine markets flourished globally because the quality of vintages could be determined within the bounds of reason. Pragmatic philosophy is well suited to assess the truth in wine narratives given that the success of vintages depends upon taste rather than Platonic ideals. Pragmatists like Richard Rorty have contended that truth is solely a cultural agreement 
aimed at promoting social progress through reason and morality. Other pragmatists like Hilary Putnam (1985: 79) believe that «[...] there really is such a thing as getting something right» even though the truth is impossible to separate from our cultural representations. Rorty (1982: xxxvii) has since modified his position to allow that objective truth matters to the extent that revised philosophical inquiries «[...] come to seem clearly better than their predecessors». The difficulties encountered by philosophers in evaluating the truth in narratives should come as a relief to connoisseurs, who rely upon personal experience to assess the excellence of vintages. Rating the quality of wine by region and history is further complicated by the shipment of grafts overseas. French vine clippings exported to the New World were repatriated successfully to restore vineyards decimated by Phylloxera insects in the late $19^{\text {th }}$ century. Renewed French harvests were deemed superior to those abroad using grapes with identical genetic markers. So pragmatic philosophy can help us deflate Hal's idealistic opposition to wine and place a fig leaf on Falstaff's wine-soaked claims to embody classical virtues.

Renaissance diplomacy had no predominant international language, but wine was the principal beverage fueling global relations. Once peace treaties with European competitors like Spain and Holland restored England's access to established wine markets, a remarkably strong bond formed between James I and Spanish ambassador de Acuña, known to Londoners as Gondomar, a controversial figure owing to his extravagant lifestyle. Despite this fast friendship, England and Spain worked assiduously to uncover state secrets. Attorney General Coke accused the Earl of Somerset of treason for sharing with Gondomar «the contents of other Ambassadors' letters, to the great danger of the King and kingdom» (Green, $1858 a$ : 348). James's agents bribed Spanish innkeepers to gain access to letters destined for the King of Spain before they reached his hands. James was informed of Gondomar's unflattering portrayal of his eating and drinking «so recklessly that it is thought he will not be long lived» (Green, 1858 a: 199). Notwithstanding harsh diplomatic critiques, James and Gondomar toasted one another warmly during frequent state and private gatherings.

Pragmatism also governed the treatment of French merchants in British courts. René Girault's 120 tuns of French wine were seized by British customs because he hired a Flemish ship to haul his cargo across the Channel. But Girault won his 1622 suit by explaining that, despite his best efforts to find appropriate transportation for his wine barrels, «[...] there was no English nor Scottish vessel of Nantes in which they could be carried over» (Green, 1858 $b$ : 467). The British Admiralty relaxed its exacting standards to accommodate 
Girault. Moreover, French wines were treated favorably relative to vintages from the Levant, Greece, and southern Spain. The more remote the vintage, the more the English crown asserted its control over imports. This policy allowed James to cultivate relations with the Far East. Ambassador Thomas Roe tells of a diplomatic success resulting from James's gift of wine to Emperor Jahangir and his son in Ajmer, India: «Never saw men so enamoured of drink as the king and prince are of red wine; think four or five handsome cases will be more welcome than the richest jewel in Cheapside» (Sainsbury, 1862: 455). Diplomatic narratives about Far Eastern wealth encouraged British rulers to manage the wine trade with distant regions.

France made a pragmatic decision to invest heavily in agricultural production rather than munitions. Several months before the sailing of the Spanish Armada, Henri IV asked Elizabeth's permission to purchase British stores and armaments for La Rochelle's defenses from «Anthoine Stanleck, marchand de Londres, de charger les vivres et munitions de guerre» (Xivrey, 1853: 321). Butter was the sole agricultural product Henri requested of Britain, indicating that France suffered no shortage of food or wine. Sully confirms that Henri taxed «vins de la province de Champagne» to pay for military expenses (Mallevoüe, 1911: 306). France preferred developing long-established wine markets because arms could be acquired as needed. Wine became one of three agricultural staples underpinning the French economy, whose markets were reported by Thomas Overbury (1651: 77) in 1609 to be the «fairest and richest of all Christendom». Grain from the interior, salt from coastlines, and wine from Bordeaux, Burgundy, and Champagne placed French agriculture on a solid footing. James I discovered to his chagrin the special privilege England assigned to reliable French wines. Sir Edwin Sandys denounced James's excessive taxation of French wine as a violation of a "covenant with the farmers of customs, they comparing their suffering under him [...] to those of the Israelites under their task-masters» (Green, 1859: 213).

Pragmatism guided James's leasings of wine monopolies, although he issued them so hastily that their jurisdictions sometimes overlapped, much to the consternation of the English nobility, who expected exclusivity in their importation rights. The Company of the Vintners of London obtained a lease to sell wine in the city, but James granted the same privilege to many individuals and taverns. The multiplication of wine leases involving cities, ports, and the Admiralty in Southampton created a flurry of petitions in England's law courts. James resolved his errors pragmatically rather than attempt to enforce contradictory edicts. The port of Southampton received duties on wine even if the cargo was offloaded in London. In 1613, vintners pressured James to 
reduce fees by threatening to halt sales of the «wines of Bourdeaux» (Green, $1858 b$ : 342). James's affinity for European alliances and the growing influence of British traders forced him to placate the wine marketplace.

Early modern British rulers accommodated their subjects' desire to consume all available French vintages. Philip Green's inventory of French table wine increased due to the arrival of an unexpected shipment, forcing him to petition Charles I for the right to sell the excess product in London. As Charles's wine merchant, he supplied the first choice in vintages to the crown, followed by the nobility, but his oversupply required him to «vend the same at his private abode by bottle» (Bruce, 1858: 365). Green foresaw the profit in transferring wine from barrels to bottles roughly one century before the vintners of Champagne agreed to undertake this risky «transformation» (Brennan, 1991: 250). Imports of Mediterranean sack (sakke) declined in relative terms, although Falstaff's testimony proves that the market in sweet wines had not disappeared entirely. Sack reached the height of its popularity in the early $15^{\text {th }}$ century, when the supply was so plentiful that exporters accepted two-thirds payment in cloth and one-third in cash. Venetian ambassador Sebastian Giustinian (1854: 46) reports that English traders concealed «deceitful [mixed] cloth» within fine textiles to conclude these transactions with the result that the inferior linen undermined England's vital exports of plain textiles. Yet European exporters of sack cut corners as well by reducing the volume of sweet wine per barrel, confusing tabulations by British customs agents. No ruler stood to gain from subterfuge even though royal levies encouraged marginal players in the wine marketplace to resort to devious schemes. Early modern British wine traders resolved commercial irregularities pragmatically by dealing mainly with elite marketplaces.

\section{Mistaken Self-Identity in Shakespeare's Globalized Wine Markets}

Both Hal and Falstaff prey upon wine culture in Shakespeare's staging of the difference between marketplaces and a globalized economy. Neither character's morals are fully developed from a pragmatic marketplace perspective. Hal seeks to affirm his legitimacy by breaking the very wine market that finances his regime. His investment in an idealistic narrative about reformation and legitimacy leads him to risk a global economic crisis by threatening France's vineyards with destruction in order to ensure the success of his invasion. He uses the apocalyptic language of war against nature herself. As well, he rationalizes his doubts about his legitimacy by magnifying Falstaff's flaws. 
Falstaff engages in petty marketplace fraud and theft to receive wine and conscripts, but he does not reject markets per se. Bloom (1987: 2) holds that Shakespeare inaugurates our modernity by representing Falstaff's «supreme immanence» as a body lacking a superego: «We cannot see how original Falstaff is because Falstaff contains us; we do not contain him». But Bloom's Freudian analysis ignores Falstaff's identification with classical wine narratives that, on his understanding, surpass all others to such a degree that they represent the truth itself. On the pragmatic level, then, Shakespeare links Hal's mistaken self-identity to an unethical brand of globalization, representations of which contribute to the depression of national economies to this very day.

Hal buffers himself from illegal acts that flow inevitably from aggressive global economic aims. He divests himself of moral responsibility by blaming the destructiveness of war on the personal sins of others. He shows his familiarity with the discourse of the marketplace by misleading us about his intention to profit from the looming civil war: «[...] we shall buy maidenheads as they buy hob-nails, by the hundreds» (1597, 2.4:299-300). Hal restrains his libido but not his desire to globalize wine markets. He proposes sacrificing a prestigious marketplace to justify his narrative of (eventual) moral rectitude, although his preference is to seize France's vineyards. He could just as easily claim that his assault on French agriculture expiates Falstaff's sin of gluttony; however, corn, salt, sauce, and gravy are not as glamorous as wine. Wine is the symbolic elixir that offers Hal the greatest hope that his false narrative might gain a purchase on redemptive truth.

The centuries-old debate over whom we should prefer, Hal or Falstaff, is a reflection of character criticism that fades into inconsequentiality given the play's pragmatic resolution of conflicts between moral ideals and the wine trade. Tom McAlindon (2001: 100) may well be correct that Falstaff's arsenal of biblical quotations derives from Shakespeare's «audacious caricature» of a Protestant heretic (Sir John Oldcastle) executed by the historical Henry V. But Falstaff's self-assured wit owes to his belief in his identity with classical conceptions of wine as the prime mover of health, swordsmanship, and knowledge. Thus, Hal and Falstaff have different reasons for scorning taverns that adulterate sack. Hal's worry is that his drink is a «bastard» variety, while Falstaff reproves Poins for spoiling the taste of his sherry: "You rogue, here's lime in this sack too» $(1597,2.4: 64 ; 2.4: 105)$. Falstaff's observations pertain to quality; however, not even Galen's pragmatic teachings could deflect Hal from his quest for moral redemption. Hal pretends to rise above the market for festive beverages while acknowledging his fondness for small beer (but 
not wine). Yet his victory over France is conditioned by a narrative whose language betrays his legacy in the wine marketplace.

Hal's narrative justifying his descent into the wine marketplace in order to redeem himself upon his accession to the throne requires him to deny that Renaissance wine traders raise the quality of English culture. Material improvements in the British wine marketplace owe mainly to the professionals themselves. Speaking on behalf of their brethren in other localities, the Vintners of Salisbury demand to know «what measure all Her Majesty's gaugers gauge and measure by» in accounting for wine imports (Green, 1872: 81). Their insistence on marketplace quality complicates Walter Cohen's (2001: 143) cultural materialist narrative that Falstaff obeys a dominant Renaissance «logic of mercantilist exchange» in a «counter-courtly tavern setting» by treating others as commodities. For the excellence sought by Falstaff and British wine traders supervenes upon reductionist economic theories. Indeed, duties collected by the port of Southampton were imposed by Philip II of Spain. Upon arriving in England to wed Queen Mary, Philip was taken aback at the harbor's state of disrepair. As an experienced wine trader who no doubt saw Southampton as a future point of entry for Spanish vintages, Philip understood that wine markets required investments even if Mary did not. Wine traders balked at paying excessive duties but sought out the best products to satisfy their eager clients.

Hal's rejection of Falstaff, wine, and the wine marketplace is central to his myth of redemption. Despite her lack of familiarity with the English language, Princess Katherine of France agrees to an alliance with Hal contingent upon his sparing French markets and culture. Hal remains silent about vacant wine markets and untended vineyards resulting from his invasion, but he cannot suppress old marketplace discourse in his haste to conclude a marriage compact with Katherine that would grant him control of France: "Give me your answer, i'faith do, and so clap hands and a bargain» (1599, 5.2: 124-125). The intrusion of rough marketplace language in the refined discourse of courtship and diplomacy is comical and revealing. Ultimately, Hal cannot alienate himself from wine marketplaces because their cultural value exceeds his false idealism and violent methods of globalization. Chorus's prophecy of the brevity of his reign assures the audience of the continuity of the wine marketplace despite his creation of an artificial global economic crisis.

The true importance of the wine marketplace to Renaissance culture is revealed by a French nobleman on the losing side. Burgundy sues for peace with England to save France's «vine, the merry cheerer of the heart» (1599, 5.2: 41). The dramatic action shows that wine's celebratory value depends 
upon concerted marketplace activity extending to representations in drama and diplomacy. Shakespeare distinguishes between narratives of sustainable wine markets and those of the global economy, whose representations shroud financial malpractice in secrecy. Although Falstaff fails to adhere to his cherished classical wine narrative by succumbing to the lure of drink, he identifies Hal as a marketplace interloper who fortifies his cold blood with «excellent endeavour of drinking good and good store of fertile sherris, that he is become very hot and valiant» $(1598,4.1: 467-469)$. Like today's defenders of global economic principles, Hal disclaims responsibility for financial crises by holding hostage popular representations of the most prestigious marketplaces, wine being foremost among them. Philosophers differ on the merits of idealism and natural philosophy, mistaken versions of which Hal and Falstaff adopt as their identities, but pragmatism validates fair representations of vital wine marketplace cultures lasting to the present day.

\section{References}

Bain, J. (ed.) (1888): Calendar of Documents Related to Scotland, vol. 4, Edinburgh, HM General Register House.

BLoom, H. (ed.) (1987): Shakespeare's Henry IV, Part 1, New York, Chelsea House.

BRenNan, T. (1991): Burgundy to Champagne: The Wine Trade in Early Modern France, Baltimore, Johns Hopkins University Press.

Bruce, J. (ed.) (1858): Calendar of State Papers, Domestic, Charles I, 1625, 1626, London, HMSO.

Cohen, W. (2001): «The undiscovered country: Shakespeare and mercantile geography» in Howard, J.; S. Shershow (eds.) (2001): Marxist Shakespeare, Routledge, London. 128-158.

Digges, D. (1655): The Compleat Ambassador, London, Newcomb.

Giustinian, S. (1854): Four Years at the Court of Henry VIII, 1515-1519, London, Cornhill.

Green, M. (ed.) (1872): Calendar of State Papers, Domestic, Elizabeth and James I, Addenda, 1580-1625, London, HMSO.

- (1858 a): Calendar of State Papers, Domestic, James I, 1611-1618, London, HMSO.

- (1858 b): Calendar of State Papers, Domestic, James I, 1619-1623, London, HMSO. 
- (1859): Calendar of State Papers, Domestic, James I, 1623-1625, Addenda, London, HMSO.

Hancock, D. (2009): Oceans of Wine: Madeira and the Emergence of American Trade and Taste, New Haven, Yale University Press.

Johnson, I.; G. HorsLey (eds.) (2011): Method of Medicine / Galen, vol. 2, Cambridge, Harvard University Press.

LACHIVer, M. (1988): Vins, vignes et vignerons: histoire du vignoble Français, Paris, Fayard.

Maddison, R. (1641): Englands Looking In and Out, London, Badger.

Mallevoüe, M. (ed.) (1911): Les Actes de Sully 1600-1610, Paris, Imprimerie Royale.

Mcalindon, T. (2001): «Perfect Answers: Religious Inquisition, Falstaffian Wit», Shakespeare Survey, 54, Holland, P. (ed.): 100-107.

Overbury, T. (1651): Observations upon the Provinces United / And on the State of France, London, Maxey.

Putnam, H. (1985): «A Comparison of Something with Something Else», New Literary History, 17: 61-79.

REID, A. (1989): «Elephants and Water in the Feasting of Seventeenth Century Aceh», Journal of the Malaysian Branch of the Royal Asiatic Society, 62 (2): $25-44$.

RoRTy, R. (1982): Consequences of Pragmatism (Essays 1972-1980), Minneapolis, University of Minnesota Press.

Sainsbury, W. (ed.) (1862): Calendar of State Papers Colonial, East Indies, China, Japan, 1513-1616, London, HMSO.

Shakespeare, W. (1597): The First Part of King Henry IV, Weil, H.; J. WeIL (eds.) (2007), updated ed., Cambridge, Cambridge University Press.

- (1598): The Second Part of King Henry IV, Merchiori, G. (ed.) (2007), updated ed., Cambridge, Cambridge University Press.

- (1599): King Henry V, GurR, A. (ed.) (2005), updated ed., Cambridge, Cambridge University Press.

Turner, W. (1562): A New Boke of the Natures and Properties of all Wines that are commonly used here in England, London, Seres.

XIVRey, B. (ed.) (1843): Recueil des Lettres Missives de Henri IV, 1585-1589, Paris, Imprimerie Royale. 